\title{
SELF DEVELOPMENT TRAINING BAGI KARANG TARUNA DESA PENGALANGAN KECAMATAN MENGANTI KABUPATEN GRESIK
}

\author{
Firsty Oktaria Grahani ${ }^{1}$, Aironi Zuroida ${ }^{2}$, Nina Permei Sela ${ }^{3}$, Shinta Nuriyah ${ }^{4}$ \\ ${ }^{1234}$ Universitas Wijaya Putra
}

oktaria@uwp.ac.id, aironizuroida@uwp.ac.id,ninapermeisela@gmail.com, shintadinda78@gmail.com

\begin{abstract}
Abstrak
Karang taruna memiliki tugas mengembangkan potensi generasi muda dan masyarakat; berperan aktif dalam pencegahan dan penanggulangan permasalahan sosial melalui rehabilitasi sosial, jaminan sosial, pemberdayaan sosial, dan perlindungan sosial serta program prioritas sosial, bekerjasama dengan pemerintah daerah provinsi, pemerintah daerah kabupaten/ kota, kecamatan, desa atau kelurahan, potensi sumber kesejahteraan sosial, badan usaha, atau masyarakat. Permasalahannya, kurangnya kesadaran akan tanggung jawab sosial dalam antisipasi mencegah berbagai permasalahan sosial; rendahnya kesadaran dalam pengembangan karakter generasi muda yang berpengetahuan, berkepribadian, terampil, cerdas, inovatif dan berkarya; kesulitan dalam mengumpulkan anggota karang taruna. Tujuannya, setiap anggota karang taruna mampu mengidentifikasi, memahami dan mampu mengembangkan potensi diri dan mengimplementasikan dalam kegiatan-kegiatan di karang taruna, anggota karang taruna lebih memahami tentang pengelolaan manajemen organisasi yang efektif dan pola kepemimpinan yang efisien, setiap anggota karang taruna memiliki kepekaan dan kepedulian yang lebih baik dalam menyelesaikan persoalan sosial yang terjadi di sekitarnya serta berkontribusi aktif dalam pengembangan desa. Metode pelaksanaan yang digunakan dalam program pemberdayaan ini, yaitu pelatihan mengenai manajemen organisasi, kepemimpinan, self awareness, pengenalan dan pengembangan diri, dan pengendalian motivasi yang dilakukan secara bertahap. Hasilnya beberapa anggota karang taruna memahami tentang ruang lingkup organisasi karang taruna, menemukan potensi diri yang dimiliki sehingga mampu menyampaikan gagasan terkait pengembangan potensi desanya.
\end{abstract}

Kata Kunci : Self Development Training, Pemberdayaan Karang Taruna

\section{PENDAHULUAN}

Karang taruna adalah salah satu jenis organisasi kepemudaan di Indonesia yang dijadikan wadah untuk mengembangkan kemampuan atas dasar kesadaran dan tanggungjawab dalam suatu daerah khususnya di desa yang ditempati. Sebagai wadah pengembangan potensi generasi muda karang taruna memiliki landasan hukum yang jelas, yaitu Peraturan Menteri Sosial Republik Indonesia Nomor 25 Tahun 2019 tentang Karang Taruna yang menyatakan bahwa karang taruna adalah organisasi yang dibentuk oleh masyarakat sebagai wadah generasi muda untuk mengembangkan diri, tumbuh dan berkembang atas dasar kesadaran serta tanggungjawab sosial dari, oleh, dan untuk generasi muda, yang berorientasi pada tercapainya kesejahteraan sosial bagi masyarakat.

Karang taruna memiliki tugas, yaitu mengembangkan potensi generasi muda dan masyarakat; berperan aktif dalam pencegahan dan penanggulangan permasalahan sosial melalui 
rehabilitasi sosial, jaminan sosial, pemberdayaan sosial, dan perlindungan sosial serta program prioritas sosial. Dalam melaksanakan tugasnya karang taruna bekerjasama dengan pemerintah, pemerintah daerah provinsi, pemerintah daerah kabupaten/ kota, kecamatan, desa atau kelurahan, potensi sumber kesejahteraan sosial, badan usaha, atau masyarakat. Untuk dapat mencapai sasaran tersebut, maka karang taruna bersama-sama dengan pemerintah dan komponen masyarakat lainnya menanggulangi berbagai masalah pembangunan sehingga potensi karang taruna dapat dirasakan oleh masyarakat di lingkungannya.

Fenomena yang terjadi adalah munculnya beberapa permasalahan dalam organisasi karang taruna di berbagai daerah di Indonesia. Beberapa permasalahan yang dihadapi oleh karang taruna di berbagai daerah di Indonesia dalam konteks pembangunan nasional di kalangan generasi muda, antara lain : 1) kegiatan Karang Taruna yang masih bersifat "mendaur ulang" kegiatan yang sudah ada sebelumnya dan hanya menjadi sekedar pengisi waktu luang; 2) kurangnya SDM profesional; 3) kurang tanggapnya anggota karang taruna terhadap proses pengembangan kualitas Karang Taruna; 4) kekacauan dalam penyelenggaraan organisasi sebagaimana lazimnya sebuah organisasi yang dikelola oleh kaum muda; 5) keraguan Pemerintah Desa terhadap potensi Karang Taruna sehingga sedikit diberi peluang pada peran pembangunan; 6) budaya dan etos kerja organisasi yang memang terus menuntut peningkatan seiring dengan perubahan para pemuda

Berdasarkan hasil wawancara dengan Kasi Pemerintahan sekaligus koordinator Karang Taruna desa Pengalangan ditemukan beberapa permasalahan berkaitan dengan karang taruna desa Pengalangan, yaitu kurangnya kesadaran akan tanggung jawab sosial dalam antisipasi, mencegah dan menangkal berbagai permasalahan sosial; rendahnya kesadaran dalam pengembangan karakter generasi muda yang berpengetahuan, berkepribadian, terampil, cerdas, inovatif dan berkarya; dan kesulitan dalam mengumpulkan anggota karang taruna.

\subsection{Profil Mitra Karang Taruna Desa Pengalangan}

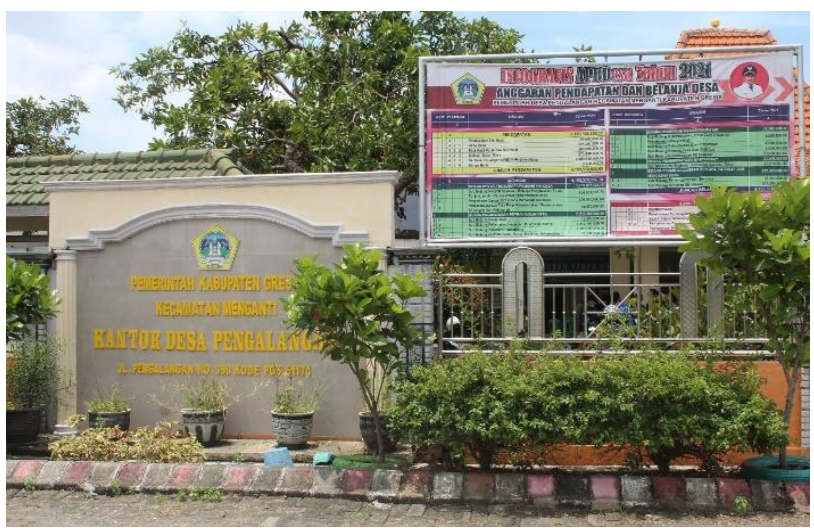

Desa Pengalangan terletak di wilayah selatan Kabupaten Gresik. Desa Pengalangan adalah salah satu Desa di Kecamatan Menganti, yang terletak berdekatan dengan wilayah kota surabaya. Desa Pengalangan mempunyai enam dusun sebagaian wilayah $\pm 482 \mathrm{H}$ penduduk \pm 5800 jiwa. Sebagian penduduk mata pencahariannya sebagaian petani dan pedagang.

Berdasarkan data sensus penduduk tahun 2019 diperoleh data bahwa jumlah penduduk tertinggi desa Pengalangan berada pada usia 26-55 tahun sebesar 42,6\% kemudian tertinggi kedua pada rentang usia 16-25 tahun sebesar 19,7\%. Dua kategori rentang usia tersebut termasuk dalam kategori usia produktif dan termasuk dalam rentang usia ideal anggota karang taruna sesuai dengan Permensos RI No.25 tahun 2019 yang menyatakan bahwa keanggotaan karang taruna menganut sistem stelsel pasif yaitu setiap generasi muda yang berusia 13 (tiga belas) sampai dengan 45 (empat puluh lima) tahun otomatis menjadi anggota karang taruna.

Kondisi di lapangan, organisasi karang taruna yang cukup aktif adalah karang taruna dari bongso wetan dan bongso kulon dengan estimasi jumlah anggota aktif sekitar lima belas (15) orang dari setiap desanya, sehingga dapat dikatakan sekitar tiga puluh (30) orang anggota yang aktif dalam karang taruna, dengan rincian dua puluh empat (24) orang anggota karang taruna terdiri dari laki-laki dan enam (6) orang anggota perempuan. Sedangkan berdasarkan demografi usianya, 
rangenya antara usia 17- 30 tahun. Kegiatan karang taruna yang dilakukan selama ini masih sebatas kegiatan peringatan kemerdekaan dan sedekah bumi sehingga belum ada aktivitas yang inovatif dan produktif yang dilakukan sebagai salah satu usaha dalam pengembangan desa yang dilakukan.

\subsection{Permasalahan Mitra}

Berdasarkan kondisi objektif sebagaimana terurai dalam analisis situasi di atas, maka permasalahan mendasar yang dihadapi karang taruna desa Pengalangan dalam pengembangan organisasi dapat diklasifikasikan dalam tiga dimensi, yaitu kognitif, afektif dan psikomotor sebagai berikut :

Tabel 1.Permasalahan Prioritas Mitra

\begin{tabular}{|c|c|c|}
\hline No. & Aspek & Permasalahan Mitra \\
\hline \multirow[t]{3}{*}{1.} & \multirow[t]{3}{*}{ Kognitif } & $\begin{array}{l}\text { Kurangnya kesadaran } \\
\text { mengenai pentingnya } \\
\text { keberadaan pemuda di } \\
\text { tengah proses } \\
\text { pengembangan desa. }\end{array}$ \\
\hline & & $\begin{array}{l}\text { Kurangnya pengetahuan } \\
\text { tentang manajemen } \\
\text { organisasi dan } \\
\text { kepemimpinan. }\end{array}$ \\
\hline & & $\begin{array}{l}\text { Kurangnya pemahaman } \\
\text { tentang pentingnya karang } \\
\text { taruna sebagai wadah } \\
\text { pengembangan pemuda } \\
\text { dalam peningkatan } \\
\text { kesejahteraan sosial. }\end{array}$ \\
\hline \multirow[t]{2}{*}{2.} & \multirow[t]{2}{*}{ Afektif } & $\begin{array}{l}\text { Kurangnya kepekaan dan } \\
\text { kepedulian terhadap } \\
\text { permasalahan-permasalahan } \\
\text { sosial yang berkembang. }\end{array}$ \\
\hline & & $\begin{array}{l}\text { Kurangnya keberanian } \\
\text { untuk mencoba hal-hal baru } \\
\text { dan berpikir keluar dari } \\
\text { zona nyaman. }\end{array}$ \\
\hline \multirow[t]{2}{*}{3.} & \multirow[t]{2}{*}{ Psikomotor } & $\begin{array}{l}\text { Kurang berkembangnya } \\
\text { kemampuan berpikir kreatif, } \\
\text { inovatif dan produktif } \\
\text { dalam usaha pengembangan } \\
\text { potensi desa. }\end{array}$ \\
\hline & & Kurangnya kemampuan \\
\hline
\end{tabular}

\begin{tabular}{|l|l|}
\hline & dalam memotivasi diri \\
& untuk selalu berpikir \\
produktif dan memobilisasi & pemuda lain pada suatu \\
& tujuan tertentu. \\
\cline { 2 - 2 } & $\begin{array}{l}\text { Kurangnya kemampuan dan } \\
\text { ketrampilan dalam } \\
\text { mengelola suatu organisasi. }\end{array}$ \\
\hline
\end{tabular}

\subsection{Solusi dan Target Luaran}

Tabel 2. Solusi dan Target Luaran

\begin{tabular}{|c|c|c|}
\hline $\begin{array}{c}\text { Permasa-lahan } \\
\text { Mitra }\end{array}$ & Solusi & Target Luaran \\
\hline $\begin{array}{l}\text { Kurangnya } \\
\text { kesadaran dan } \\
\text { pemaha-man } \\
\text { tentang } \\
\text { kontribusi } \\
\text { aktif para } \\
\text { pemuda dan } \\
\text { pengeta-huan } \\
\text { tentang } \\
\text { manaje-men } \\
\text { organisasi }\end{array}$ & $\begin{array}{l}\text { - Memberikan } \\
\text { pelatihan } \\
\text { mengenai } \\
\text { pengenalan } \\
\text { dan pengem- } \\
\text { bangan diri, } \\
\text { manajemen } \\
\text { organisasi } \\
\text { dan } \\
\text { kepemim- } \\
\text { pinan. } \\
\text { - Memberikan } \\
\text { edukasi } \\
\text { mengenai } \\
\text { karang taruna } \\
\text { dan segala } \\
\text { ruang } \\
\text { lingkupnya } \\
\text { (tujuan, } \\
\text { status, } \\
\text { kedudukan } \\
\text { tugas, fungsi, } \\
\text { tanggung- } \\
\text { jawab, } \\
\text { wewenang, } \\
\text { dll) }\end{array}$ & $\begin{array}{l}\text { - Setiap } \\
\text { anggota } \\
\text { karang taruna } \\
\text { mampu } \\
\text { mengidentifi- } \\
\text { kasi, } \\
\text { mengenali } \\
\text { dan } \\
\text { memahami } \\
\text { serta mampu } \\
\text { mengembang- } \\
\text { kan potensi } \\
\text { diri masing- } \\
\text { masing dan } \\
\text { mengimple- } \\
\text { mentasikan } \\
\text { dalam } \\
\text { kegiatan- } \\
\text { kegiatan di } \\
\text { karang taruna. } \\
\text { - Anggota } \\
\text { karang taruna } \\
\text { lebih } \\
\text { memahami } \\
\text { tentang } \\
\text { pengelolaan } \\
\text { manajemen } \\
\text { organisasi } \\
\text { yang efektif } \\
\text { dan pola } \\
\text { kepemim- } \\
\text { pinan yang } \\
\text { efisien dalam }\end{array}$ \\
\hline
\end{tabular}




\begin{tabular}{|c|c|c|}
\hline & & $\begin{array}{l}\text { suatu } \\
\text { organisasi. }\end{array}$ \\
\hline $\begin{array}{l}\text { Kurangnya } \\
\text { kepekaan } \\
\text { terhadap } \\
\text { permasa- } \\
\text { lahan- } \\
\text { permasa-lahan } \\
\text { sosial yang } \\
\text { berkem-bang } \\
\text { dan } \\
\text { keberanian } \\
\text { untuk } \\
\text { mencoba hal- } \\
\text { hal baru dan } \\
\text { berpikir out of } \\
\text { box }\end{array}$ & $\begin{array}{l}\text { - Memberikan } \\
\text { pelatihan } \\
\text { mengenai self } \\
\text { awareness, } \\
\text { - Mengguna- } \\
\text { kan metode } \\
\text { studi kasus } \\
\text { dan simulasi } \\
\text { untuk } \\
\text { mengetahui } \\
\text { sejauh mana } \\
\text { anggota } \\
\text { karang taruna } \\
\text { mampu dan } \\
\text { berani } \\
\text { mengaplikasi } \\
\text { kan pemahaman } \\
\text { yang mereka } \\
\text { peroleh dalam } \\
\text { kondisi riil. }\end{array}$ & $\begin{array}{l}\text { - Setiap } \\
\text { anggota } \\
\text { karang taruna } \\
\text { memiliki } \\
\text { kepekaan dan } \\
\text { kepedulian } \\
\text { yang lebih } \\
\text { baik dalam } \\
\text { menyelesai- } \\
\text { kan } \\
\text { persoalan- } \\
\text { persoalan } \\
\text { sosial yang } \\
\text { terjadi di } \\
\text { sekitarnya } \\
\text { dan } \\
\text { berkontribusi } \\
\text { aktif dalam } \\
\text { mengembang } \\
\text { kan desanya }\end{array}$ \\
\hline $\begin{array}{l}\text { Kurang } \\
\text { berkembangny } \\
\text { a kemampuan } \\
\text { berpikir } \\
\text { kreatif, } \\
\text { inovatif dan } \\
\text { produktif } \\
\text { dalam usaha } \\
\text { pengembanga } \\
\text { n potensi desa. }\end{array}$ & $\begin{array}{l}\text { - FGD untuk } \\
\text { mengetahui } \\
\text { karakteristik } \\
\text { masing- } \\
\text { masing } \\
\text { anggota. } \\
\text { - Memberikan } \\
\text { pelatihan } \\
\text { mengenai } \\
\text { pengenda-lian } \\
\text { motivasi diri. } \\
\text { - Role play, } \\
\text { simulasi, } \\
\text { merancang } \\
\text { proker karang } \\
\text { taruna yang } \\
\text { aplikatif dan } \\
\text { inovatif. }\end{array}$ & $\begin{array}{l}\text { - Setiap } \\
\text { anggota } \\
\text { karang taruna } \\
\text { mampu } \\
\text { mengaplikasi } \\
\text { kan setiap } \\
\text { potensi yang } \\
\text { dimiliki dan } \\
\text { mengaplikasi } \\
\text { kan ide-ide } \\
\text { kreatif dalam } \\
\text { mengembang- } \\
\text { kan desa. } \\
\text { - Bisa saling } \\
\text { sharing dan } \\
\text { bertukar } \\
\text { pikiran } \\
\text { mengenai ide- } \\
\text { ide kreatif } \\
\text { dalam } \\
\text { memajukan } \\
\text { desa. } \\
\text { - Mampu } \\
\text { menyusun }\end{array}$ \\
\hline
\end{tabular}

\begin{tabular}{|l|l|l|}
\hline & proker yang \\
& inovatif, \\
& kreatif, \\
& produktif dan \\
& aplikatif. \\
\hline
\end{tabular}

\section{METODE}

Adapun langkah-langkah pelaksanaan program pengabdian masyarakat ini adalah sebagai berikut:

1. Koordinasi dengan mitra terkait jadwal dan tempat pelaksanaan pelatihan.

Sasaran program pelatihan adalah anggota karang taruna desa Pengalangan. Sedianya pelatihan akan dilakukan di tempat mitra namun, karena kondisi pandemi covid-19 yang terkadang kurang kondusif sehingga segala proses pelatihan dilaksanakan secara offline dan online

2. Persiapan pelatihan.

Persiapan mencakup persiapan bahan materi bagi anggota karang taruna, pembuatan modul pembuatan instrument penilaian berupa kuisioner yang akan dibagikan sebelum dan sesudah pelatihan.

3. Pelaksanaan pelatihan.

Pelatihan dilaksanakan dengan pendekatan partisipatif dimana tim pengusul akan menyampaikan materi secara offline maupun online kepada para anggota karang taruna selama beberapa pertemuan. Setiap pertemuan menargetkan capaian bagi para anggota karang taruna hingga pada pertemuan terakhir anggota karang taruna dapat memahami potensi yang dimiliki oleh diri masing-masing anggota dan berkontribusi aktif pada organisasi karang taruna, memahami tentang manajemen organisasi dan kepemimpinan yang efektif, serta mampu mengaplikasikan ide-ide kreatif dan inovatif dalam mengembangkan potensi desa.

4. Evaluasi Proses Pelatihan

Hasil kuesioner diolah dan dianalisa untuk diketahui hasil akhir dari pelatihan apakah sesuai dengan yang diharapkan. Evaluasi ini 
berguna untuk pelatihan-pelatihan selanjutnya di program pengabdian yang lain, dan berguna juga untuk memberi tambahan informasi yang mungkin belum tersampaikan selama pelatihan kepada mitra.

5. Pemberian modul Self Development Training bagi Karang Taruna.

Tim pengusul akan memberikan modul Self Development Training bagi Karang Taruna untuk mempermudah pemahaman anggota karang taruna dan pengaplikasian pada organisasi karang taruna desa pengalangan.

6. Pembuatan jurnal ilmiah dan laporan akhir.

Sebagai luaran wajib program pengabdian ini maka kami akan membuat jurnal ilmiah dan laporan akhir ketika semua program telah selesai dilaksanakan.

\section{HASIL DAN PEMBAHASAN}

Berdasarkan alternatif solusi yang telah disepakati bersama dengan mitra, maka telah dilaksanakan self development training bagi karang taruna Desa Pengalangan Kecamatan Menganti Kabupaten Gresik dalam bentuk pemberian pelatihan yang dilakukan secara offline dan online dikarenakan kondisi pandemi covid-19. Pelatihan ini diberikan kepada perwakilan anggota aktif karang taruna yang aktif sekitar 15 orang. Dengan rincian tahapan psikoedukasi sebagai berikut:

Tabel 3. Rincian Pelatihan

\begin{tabular}{|l|l|l|l|l|}
\hline \multicolumn{2}{|l|}{ No. } & Tanggal & Aspek & Aktivitas \\
\hline 1. & 4 Sept & Kognitif & 1. Post test \\
& 2021 & & 2. Sharing \\
mengenai & \\
& & & kondisi \\
& & & karang taruna \\
& & desa \\
& & & pengalangan \\
& & (jumlah \\
& & anggota, \\
& & kegiatan- \\
& & kegiatan yang \\
& & telah \\
\hline
\end{tabular}

\begin{tabular}{|c|c|c|c|}
\hline & & & $\begin{array}{l}\text { dilakukan). } \\
\text { 3. Penyampaian } \\
\text { materi } \\
\text { pengenalan } \\
\text { dan } \\
\text { pengembanga } \\
\text { n potensi diri. } \\
\text { 4. Pemutaran } \\
\text { video tentang } \\
\text { self } \\
\text { development. } \\
\text { 5. Sharing } \\
\text { mengenai } \\
\text { kelebihan dan } \\
\text { kekurangan } \\
\text { yang dimiliki } \\
\text { diri dan } \\
\text { kontribusi } \\
\text { yang telah } \\
\text { dilakukan } \\
\text { untuk } \\
\text { organisasi } \\
\text { karang taruna. }\end{array}$ \\
\hline 2. & $\begin{array}{l}\text { 6 Sept } \\
2021\end{array}$ & $\begin{array}{l}\text { Kognitif, } \\
\text { Afektif }\end{array}$ & $\begin{array}{l}\text { 1. Review } \\
\text { materi } \\
\text { mengenai } \\
\text { pengenalan } \\
\text { dan } \\
\text { pengembanga } \\
\text { n diri. } \\
\text { 2. Penyampaian } \\
\text { materi } \\
\text { tentang } \\
\text { manajemen } \\
\text { organisasi } \\
\text { terutama } \\
\text { yang } \\
\text { berkaitan } \\
\text { dengan ruang } \\
\text { lingkup } \\
\text { karang } \\
\text { taruna. } \\
\text { 3. Materi } \\
\text { mengenai } \\
\text { kepemimpina } \\
\text { n yang } \\
\text { efektif. }\end{array}$ \\
\hline
\end{tabular}




\begin{tabular}{|c|c|c|c|}
\hline & & & $\begin{array}{l}\text { 4. Role play } \\
\text { berkaitan } \\
\text { dengan } \\
\text { materi } \\
\text { kepemimpina } \\
\text { n yang } \\
\text { efektif. }\end{array}$ \\
\hline 3. & $\begin{array}{l}\text { 8 Sept } \\
2021\end{array}$ & $\begin{array}{l}\text { Kognitif } \\
\text { Afektif }\end{array}$ & $\begin{array}{l}\text { 1. Review } \\
\text { materi } \\
\text { manajemen } \\
\text { organisasi } \\
\text { dan } \\
\text { kepemimpina } \\
\text { n efektif. } \\
\text { 2. Studi kasus } \\
\text { mengenai } \\
\text { karang taruna } \\
\text { yang } \\
\text { berkontribusi } \\
\text { aktif untuk } \\
\text { desa dan } \\
\text { berhasil } \\
\text { mengembang } \\
\text { kan potensi } \\
\text { desanya } \\
\text { dengan baik. }\end{array}$ \\
\hline 4. & $\begin{array}{l}11 \\
\text { Sept } \\
2021\end{array}$ & $\begin{array}{l}\text { Kognitif } \\
\text { Afektif }\end{array}$ & $\begin{array}{ll}\text { 1. } & \text { Penyampaian } \\
\text { materi } \\
\text { mengenai } \\
\text { pengendalian } \\
\text { motivasi } \\
\text { 2. } \\
\text { Pemutaran } \\
\text { video } \\
\text { tentang } \\
\text { motivasi. } \\
\text { 3. Sharing } \\
\text { mengenai } \\
\text { video yang } \\
\text { telah dilihat. }\end{array}$ \\
\hline 5. & $\begin{array}{l}13 \\
\text { Sept } \\
2021\end{array}$ & $\begin{array}{l}\text { Kognitif, } \\
\text { Afektif, } \\
\text { Psikomo- } \\
\text { tor }\end{array}$ & $\begin{array}{l}\text { 1. Identifikasi } \\
\text { potensi yang } \\
\text { dimiliki } \\
\text { setiap } \\
\text { anggota } \\
\text { kartar, } \\
\text { kegiatan } \\
\text { yang telah }\end{array}$ \\
\hline
\end{tabular}

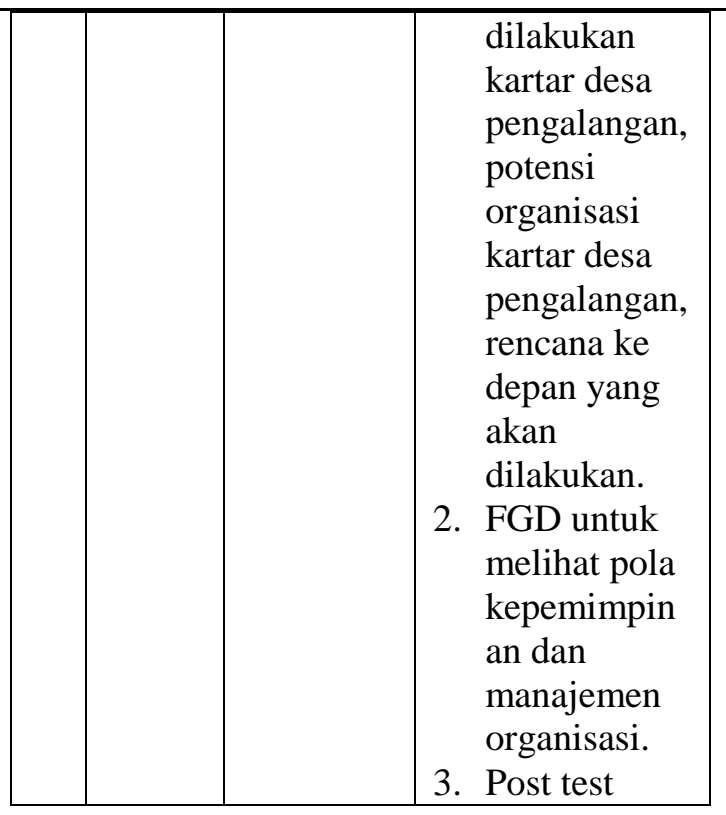

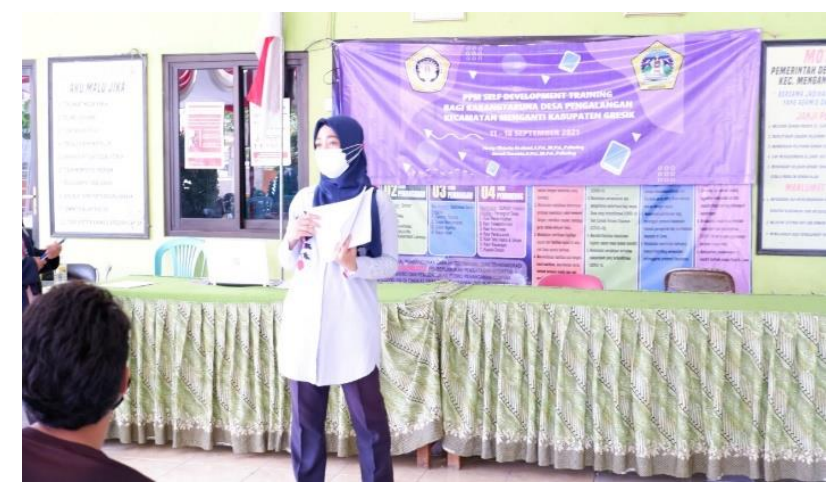

Gambar 1. Pelatihan yang dilakukan secara offline

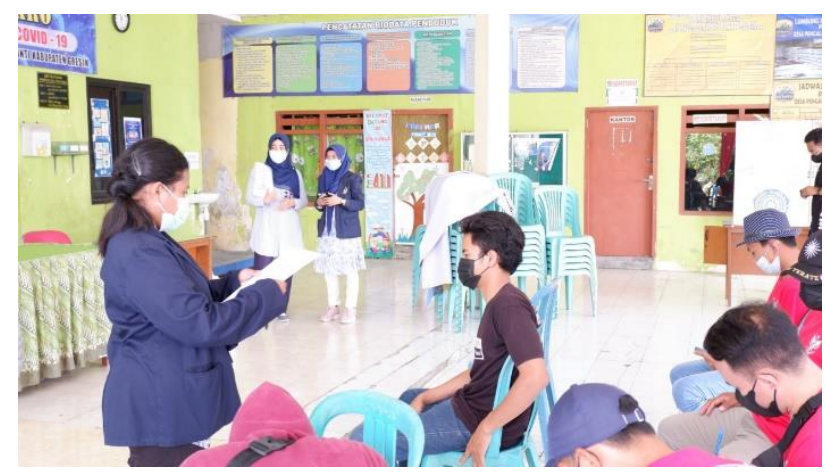

Gambar 2. Pelatihan yang dilakukan secara offline 


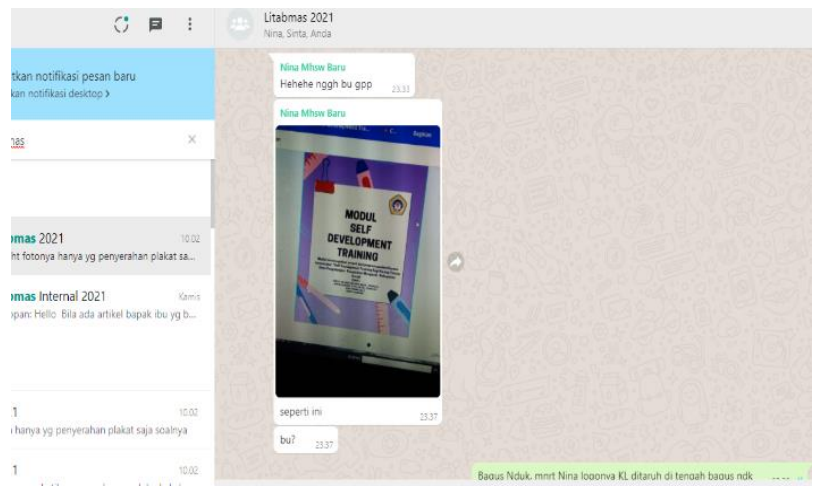

Gambar 3. Pelatihan yang dilakukan secara online melalui media wa.

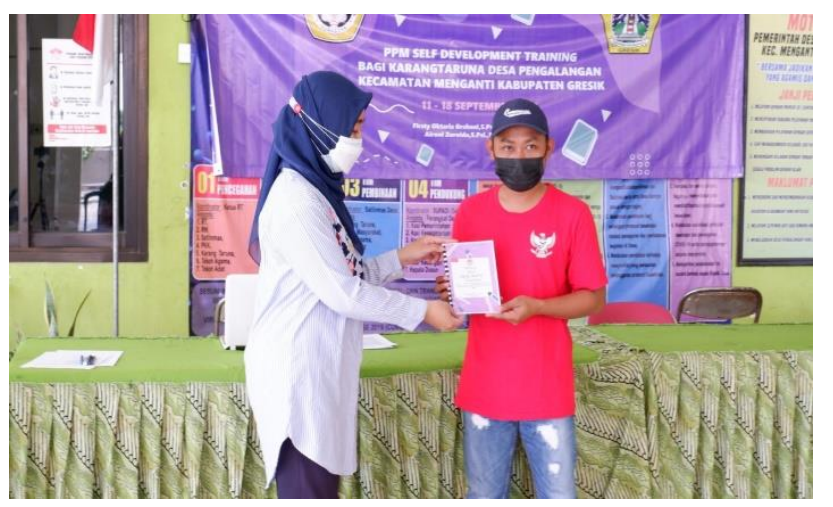

Gambar 4. Aktivitas selama pelatihan Self Development Training

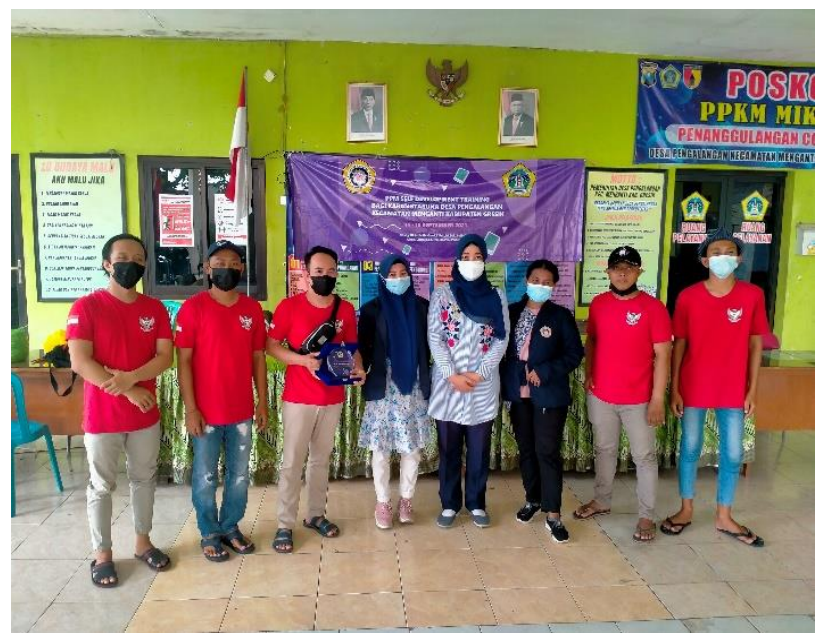

Gambar 5. Penyerahan modul kepada anggota karang taruna

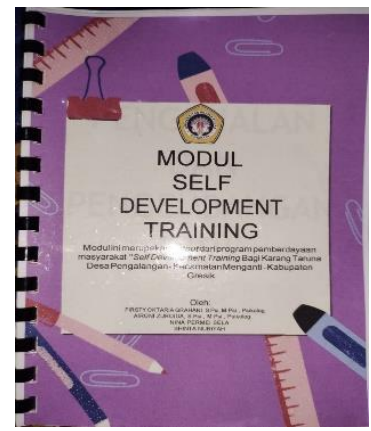

Gambar 6. Modul Self Development Training bagi Karang Taruna

Berdasarkan hasil self development training yang telah dilakukan diperoleh bahwa beberapa anggota aktif karang taruna belum memahami tentang manajemen organisasi karang taruna (tujuan, status, kedudukan, tugas, fungsi, dll) hal tersebut membuat mereka cenderung pasif dan sekedar menjadi "followers" di dalam organisasi. Setiap anggota aktif karang taruna juga sebetulnya memiliki potensi diri yang beragam hanya saja belum maksimal dalam pengembangannya karena beberapa dari mereka kesulitan dalam mengidentifikasi potensi yang dimiliki sehingga proses pengembangannya menjadi tidak maksimal. Oleh karena itu meskipun terlibat dalam karang taruna mereka kurang aware dengan sekitar, menjadi kurang inovatif dan kurang produktif dalam menciptakan hal-hal baru yang sesungguhnya dapat menjadi daya tarik yang potensial untuk proses pengembangan desa.

Penerapan self development training yang disampaikan secara aplikatif dengan menampilkan media video, studi kasus, role play, FGD, memudahkan anggota karang taruna untuk memahami materi yang disampaikan oleh pengusul. Mereka juga menunjukkan antusiasme yang cukup baik selama pelatihan berlangsung yang tampak dari 
kecepatan dalam merespon dan cukup aktif berkontribusi selama pelatihan. Kemudian terjadi proses learning yang dapat dilihat dari hasil prepost test yang diberikan, dapat dicermati bahwa para peserta lebih memahami tentang manajemen organisasi terutama berkaitan dengan karang taruna terkait tujuan, status, kedudukan, tugas, fungsi, dll secara lebih detail; memperoleh pemahaman bahwa untuk memudahkan upayat meraih tujuan/ goal setting perlu mengenali potensi yang dimiliki oleh diri. Mengembangkan potensi diri yang ada, meningkatkan kepedulian terhadap sekitar dengan berkontribusi aktif dalam pengembangan desa melalui potensi diri yang dimiliki oleh tiap-tiap anggota misalkan melalui kesenian, kebudayaan, promosi pada pihak eksternal desa Pengalangan, dll. Para anggota karang taruna desa Pengalangan juga diminta untuk melakukan identifikasi dan evaluasi terkait dengan jumlah keanggotaan karang taruna desa Pengalangan saat ini, efektivitas kegiatan yang selama ini telah dilakukan dan yang masih belum terrealisasi, potensi apa saja yang dimiliki oleh karang taruna desa Pengalangan dan rencana ke depan yang akan dilakukan untuk membantu pemerintah desa dalam pengembangan potensi desa. Saat ini kontribusi yang mulai dilakukan para karang taruna adalah dengan membantu pemerintah desa dalam pengembangan wisata petik buah, baik melalui bantuan secara riil dalam penataan lahan yang akan digunakan sebagai lokasi petik buah, menyampaikan ide dan gagasan untuk pengelolaan lahan parkirnya.

\section{KESIMPULAN}

Adapun kesimpulan dari seluruh rangkaian kegiatan ini adalah sebagai berikut :

1. Pemahaman terkait manajemen organisasi dan kepemimpinan dalam karang taruna belum dipahami secara detail. Beberapa anggota ada yang sudah paham tapi ada juga yang belum sama sekali, sehingga keterlibatan dalam organisasi kartar cenderung bersifat sebagai "followers" saja. Selain itu pola kepemimpinan dari ketua karang taruna masih belum efektif dalam memotivasi dan mengajak seluruh anggota karang taruna untuk bisa berkontribusi aktif dalam pengelolaan desa sehingga adanya self development training diharapkan dapat meningkatkan pemahaman yang mereka miliki tentang manajemen organisasi dan kepemimpinan yang efektif pada karang taruna sehingga karang taruna dapat mengembangkan organisasinya dengan lebih efektif dan efisien.

2. Pentingnya untuk mengenali dan mengembangkan potensi diri dari setiap anggota karang taruna sehingga masing-masing anggota dapat memberikan kontribusi aktif baik melalui ide, gagasan maupun keahlian yang dimiliki guna mengembangkan potensi yang dimiliki oleh desa bekerjasama dengan pemerintah desa. Self Development Training membantu para anggota karang taruna untuk mengenali dan menemukan potensi yang dimiliki oleh para anggota karang taruna sekaligus mengedukasi cara mengembangkan potensi tersebut serta langkah-langkah yang dapat dilakukan anggota karang taruna untuk dapat menjaga motivasi yang dimiliki agar tetap optimal dalam usaha pencapaian target atau tujuan yang diharapkan di setiap usaha pengembangan desa yang dilakukan.

3. Dengan adanya pemahaman terkait potensi yang dimiliki oleh masing-masing anggota karang taruna diharapkan dapat membuat mereka lebih aware dan peduli terhadap permasalahan yang ada di desa Pengalangan sehingga termotivasi untuk berpikir kreatif, inovatif dan produktif dalam menciptakan ide-ide dan gagasan baru guna berkontribusi bersama pemerintah desa di setiap program pengembangan desa. Denan ini diharapkan karang taruna dapat merancang program kerja yang inovatif, kreatif dan efisien dengan memperhatikan potensi dan keahlian yang dimiliki setiap anggotanya.

\section{UCAPAN TERIMAKASIH}

Ucapan terimakasih disampaikan kepada seluruh perangkat desa pengalangan dan anggota karang taruna yang telah terlibat dalam program pemberdayaan masyarakat Self Development 
Training bagi Karang Taruna Desa Pengalangan

Kecamatan Menganti Kabupaten Gresik

Ucapan terimakasih disampaikan juga kepada

Fakultas Psikologi Universitas Wijaya Putra dan

LPPM atas dukungannya sehingga kegiatan ini dapat terlaksana dengan baik.

\section{REFERENSI}

Data monograf profil Desa Pengalangan tahun 2019 Karang Taruna dan Tantangannya dalam Gempuran Arus Modernisasi https://www.pengadaan.web.id/2019/12/kara ng-taruna.html, (diakses tanggal 8 Desember 2019 diunduh 30 Maret 2021

Peraturan Menteri Sosial Republik Indonesia No.28 Tahun 2019 Tentang Karang Taruna

Suprayoga, Iswoyo, Syahrial, 2014, Ibm Pemberdayaan Karang Taruna, Universitas Wijaya Putra. 